\title{
Bilateral secondary spontaneous pneumothorax
}

\author{
Diana G Pedreira, ${ }^{1}$ Rita Silvério, ${ }^{1}$ Hugo J Casimiro, ${ }^{1,2}$ Jorge Mercier ${ }^{3}$
}

'Department of Internal

Medicine, Centro Hospitalar de Setúbal EPE, Setúbal, Portugal ${ }^{2}$ Instituto de Histologia e Biologia do Desenvolvimento, Faculdade de Medicina, Universidade de Lisboa, Lisboa, Portugal

${ }^{3}$ Department of Internal Medicine, Hospital da Luz Setúbal, Setúbal, Portugal

\section{Correspondence to} Dr Hugo I Casimiro, hugojorgecasimiro@gmail.com

Accepted 18 December 2017

\section{CrossMark}

To cite: Pedreira DG, Silvério R, Casimiro HJ, et al. BMJ Case Rep Published Online First: [please include Day Month Year] doi:10.1136/bcr-2017223632

\section{DESCRIPTION}

A 40-year-old male patient presented to the emergency department with complaints of shortness of breath associated with bilateral pleuritic chest pain. 40 cigarettes daily for the past 22 years.

On examination, the patient appeared breathless with a respiratory rate of 25 breaths/min and peripheral capillary oxygen saturation $\left(\mathrm{SpO}_{2}\right)$ of $92 \%$ on room air. Neck examination showed no tracheal deviation and chest examination identified decreased bilateral chest expansion with no intercostal retractions. On chest palpation, there was a slightly diminished tactile fremitus on both sides. Chest percussion revealed a hyper-resonant note heard over the right and left upper and mid zones. On auscultation, there were no audible breath sounds and whispered voice sounds were abolished over the right and left upper and mid zones.

The gasometric evaluation revealed the presence of hypoxaemia and hypocapnia. A posteroanterior chest radiograph showed a large bilateral pneumothorax (figure 1). The thoracic CT scan revealed focal areas of emphysema and apical subpleural blebs, which were located predominantly in the peripheral regions of the apex (figure 2).

Supplemental high-flow oxygen was given to the patient. After confirmation with needle aspiration, small-bore chest drains were placed on both sides and the patient had complete re-expansion of both lungs. Despite the American College of Chest Physicians Delphi Consensus Statement regarding the management of secondary spontaneous pneumothorax (SSP) and after careful discussion with a chest physician, chemical or surgical pleurodesis was not considered at this point since there was a complete resolution after the use of chest drains. From the aetiological investigation, it stood out a decreased serum level of $\alpha 1$-antitrypsin. Its He denied any history of trauma and had smoked

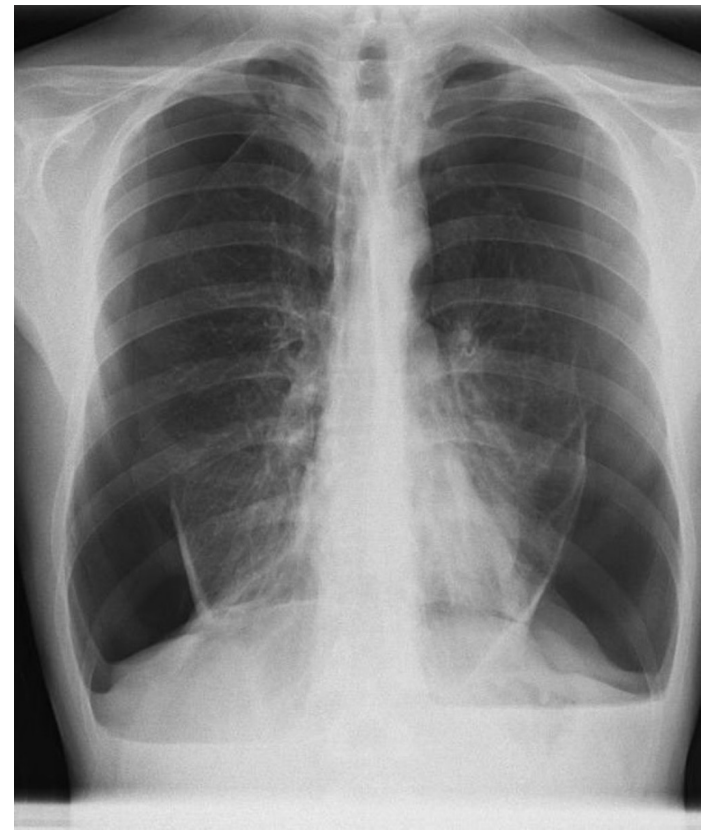

Figure 1 Posteroanterior chest radiograph showing extensive bilateral pneumothorax.

association with the high smoking load (44 pack years) in this patient was assumed to be the cause of the bilateral SSP episode. He was later discharged, being advised to cease smoking.

Several months later, he was again admitted with a new left pneumothorax. This time, after evaluation by a chest physician, he underwent a wedge resection of the left upper lobe and mechanical pleurodesis by video-assisted thoracoscopic surgery. He has remained asymptomatic since then, with no further pneumothorax recurrences.

Spontaneous pneumothorax is frequently associated with smoking habits, making smoking cessation

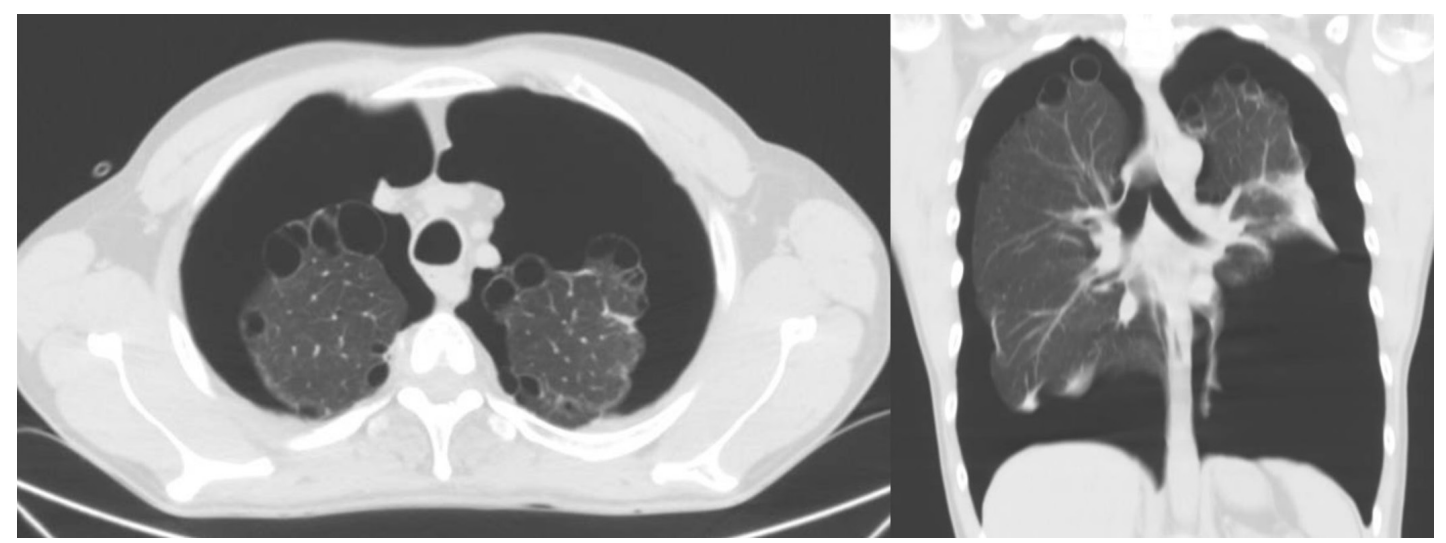

Figure 2 Thoracic CT scan (axial view on the left; coronal view on the right) showing bilateral pneumothorax with focal areas of emphysema and apical subpleural blebs. 
Learning points

- The British Thoracic Society guideline for the management of spontaneous pneumothorax is an important source of information to guide the diagnosis and treatment of patients with this condition.

- In many situations, the clinical findings do not reflect the size and severity of the pneumothorax.

- ?1-Antitrypsin deficiency is a genetic cause of pneumothorax, remaining underdiagnosed despite the strong predisposition to pulmonary conditions.

a key intervention to minimise the risk of recurrence. ${ }^{1}$ Rarer cases occur in patients with $\alpha 1$-antitrypsin deficiency. ${ }^{2}$ Despite the chest radiograph findings, a CT scan was obtained due to the case's complexity, helping to identify a possible secondary cause (emphysema and subpleural blebs). According to the British Thoracic Society guideline, we performed bilateral chest drainage along with supplemental high-flow oxygen administration since we assumed a SSP with more than $2 \mathrm{~cm}$ associated with breathless complaints. Early evaluation by a chest physician is of particular importance in patients with SSP, since some of them may require future surgical intervention such as in this case. ${ }^{1}$ Although primary spontaneous pneumothorax is usually less symptomatic than SSP, this case is particularly relevant since it describes a situation in which the patient's complaints were very sparse, despite its secondary aetiology and its bilaterality.

Contributors DGP was responsible for the overall content, including planning, conduct and reporting of the work. RS was responsible for the planning and conduct of the work, including literature search, figures and data collection. HJC and JM were responsible for conduct and reporting of the work.

Competing interests None declared.

Patient consent Obtained.

Provenance and peer review Not commissioned; externally peer reviewed.

(c) BMJ Publishing Group Ltd (unless otherwise stated in the text of the article) 2018. All rights reserved. No commercial use is permitted unless otherwise expressly granted.

\section{REFERENCES}

1 MacDuff A, Arnold A, Harvey J. BTS Pleural Disease Guideline Group. Management of spontaneous pneumothorax: British thoracic society pleural disease guideline 2010. Thorax 2010;65(Suppl 2):ii18-31.

2 McElvaney NG. Diagnosing $\alpha 1$-antitrypsin deficiency: how to improve the current algorithm. Eur Respir Rev 2015;24:52-7.

Copyright 2017 BMJ Publishing Group. All rights reserved. For permission to reuse any of this content visit

http://group.bmj.com/group/rights-licensing/permissions.

BMJ Case Report Fellows may re-use this article for personal use and teaching without any further permission.

Become a Fellow of BMJ Case Reports today and you can:

- Submit as many cases as you like

- Enjoy fast sympathetic peer review and rapid publication of accepted articles

- Access all the published articles

- Re-use any of the published material for personal use and teaching without further permission

For information on Institutional Fellowships contact consortiasales@bmjgroup.com

Visit casereports.bmj.com for more articles like this and to become a Fellow 